\title{
BEING ON THE INSIDE, FORGETTING TO LOOK OUT \\ The Need for a Historical Archaeology of Global Relevance
}

\author{
Gunhild Eriksdotter \& \\ Jonas M. Nordin
}

Historical archaeology in Scandinavia is an expanding field, but despite its global nature, the discipline is trapped in methodological nationalism. The early modern and modern societies are generally studied using the current national borders even though the material culture should not be constrained in this way. By illustrating with both theoretical and empirical examples, the objective of this paper is to bring about a greater awareness of the global nature of the material culture and the interactions that took place between peoples in Europe and beyond.

Key words: Early modern, historical archaeology, globalization, Eurocentrism, methodological nationalism, material culture, production, consumption, post-colonialism

\section{INTRODUCTION}

Globalization, a process initiated over 500 years ago, affects the world more than ever. The massive flow of goods and peoples and the flow of information and capital are today globally interwoven to a degree which is unique in human history. Although we have been living in the age of globalization for quite a while, archaeological studies of the past are still coloured by the national framework. Why do we live global lives but study national history? Is it because the past is a national concept 
and concerns the now fragmented nation-state? Or are archaeologists, too often trapped in methodological nationalism?

Historical archaeology is an expanding academic field all over the world. In particular, post-medieval and contemporaneous archaeologies are showing a rapid growth and theoretical awareness, and have at the moment a vivid, dynamic and playful status. No area of human experience or behaviour seems to be too remote for the archaeologists' sphere of interest. Any given international conference presents at least one session on the study of our recent past, such as remains of industrial societies, the Second World War or the Cold War. These materials, with their tangible connection to a collective Western remembrance, are largely revitalizing the discipline. Moreover, studies of the recent past have the means to engage archaeologists on different levels and from various sub-disciplines in contemporary debates on society. No doubt it is the archaeologists' expert skills in studying material culture, and their ability to create contact with local communities, that have provided the field with this rather unexpected success (cf. Shackel 2004; Shackel \& Chambers 2004; Little \& Shackel et al. 2007).

This is a privileged position for an academic discipline bestowed with a conservative ideology and with roots as a prime producer of national collective ideals. For a long time archaeology had an important position in the hegemonic sphere of strengthening the idea of the nation and history, and the conjunction of these two (cf. Little 2007:24-26; Nordin $2009,201 \mathrm{I})$. In the fruitful process from the grand producer of nationally "useful history" to an innovative and critical study of material culture, the spread of ahistorical interpretations is somewhat confusing and surprising. The material culture, even though contemporary, is almost exclusively studied from a national framework of interpretation. Material traces of 20 th-century conflicts are often seen from a national point of view although they have regional or even global connections. For instance, a bomb crater from the Second World War can hardly be understood without taking global aspects into account, just as the clay pipes from 17 th-century Gouda cannot be understood without considering the tobacco plantations of Maryland or Virginia.

The study of post-medieval societies in archaeology is oddly enough suffering even more from national or Eurocentric agendas. However, the source material clearly points towards an escalating internationalization since the 15 th century. Early modern industrialization, modes of production, commerce and consumption are still interpreted as either local events or part of a national process of improvement. Clearly these extensive transformations reflect global significance and are, in fact, quite hard to understand solely from a national framework (cf. Foster I999). 


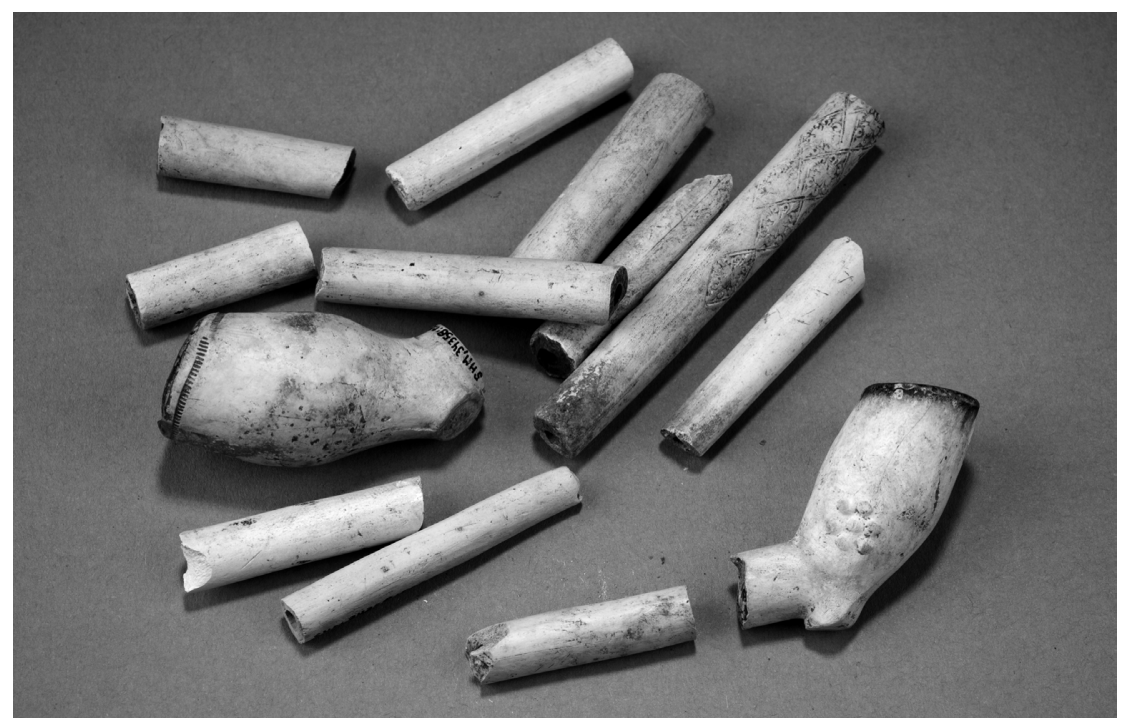

Figure I. This is not fragments of clay pipes but a tacit link to the slave plantations of the New World. Clay pipes from the middle of seventeenth-century silver works of Silbojokk, Lapland. Inv no 34 358, National Historical Museum. Photo by Christer Åhlin.

Historical archaeology in the Nordic countries needs to incorporate European colonial expansion with its worldwide connections and encounters with non-European peoples that often have been given a modest role in the analysis of European imperialism, modernity and capitalism. The perception that colonial Europe was operating as a hermetically sealed unit has nevertheless been criticized previously, for example by Matthew Johnson who asks how we can explain social and economical change when denying the slave trade that made merchant families rich beyond dreams, and their far-away plantations where they developed their own savage society (Johnson 2006:3 I3; cf. Said I993:95-II6)? Still, the discipline is short of concrete examples of how these ideas can be transformed into practice.

The aim of this article is to acknowledge some limitations of today's historical or contemporary archaeologies, and to encourage archaeologists in Scandinavia to broaden the interest in the outside world. Our belief is that, in order to get historical archaeology recognized as an important field of expertise, we need to break away from methodological nationalism and look at our source materials and questions as global. Consequently, our ambition is not to address solely archaeologies and histories of the 'outside', but rather to put the spotlight on the composite web of global interactions, relations and influences that can be seen in the early modern material culture in the Nordic countries. What is 
the material culture of modern society if not a hybridization of the Old and the New World, of feudalism, mercantilism and capitalism, and of colonialism, regionalism and nationalism?

In other words, our ambition is to give some insights into how deeply rooted the 'outside' was in 'inside' production and consumption patterns as well as cultural and social practices, but without producing new dichotomies. That said, some readers might criticize us for being ambivalent, for upholding the same Eurocentric or North Atlantic perspective that we say we want to be free of. But then, one has to remember that historical archaeology is an immense modern project with strong Eurocentric connotations even in global themes, such as colonisation, trade and contact (cf. Orser 1996; Funari 1999; Hall \& Silliman 2006:9). To free ourselves from this Eurocentric maze is a tempting and important challenge; however, it demands a much deeper discourse regarding archaeology as a Western discipline. Unfortunately, such an elaboration lies beyond the scope of this article (cf. Thomas 2004).

The article begins with a critical discussion on the methodological nationalism that still prevails in historical archaeology in both a theoretical and a historical sense (Chernilo 2008), and is followed by a presentation of two areas of limitations which are necessary to recognize in order to develop historical archaeology. Subsequently, we will clarify some of our main standpoints regarding future archaeological studies. This discussion is followed by two interrelated areas of challenges which focus firstly on the consumption of the New World, secondly on production and the birth of capitalism. As a conclusion, we encourage every archaeologist working foremost within the early modern and modern periods to get rid of the steel walls of the national power container as it has been discussed by Anthony Giddens (1987:13) and look at the past as it was: global, hybrid and polyphonic.

The modern past with its migrations, meetings and material culture has often been described through the assumption that the national state is and was the natural form of society (Wimmer \& Glick Schiller 2002:30I). This has meant that the negotiations, hybridizations and creolizations of the past rarely have been acknowledged, least of all in Scandinavia. This article sets out to criticize this limitation of prevailing nationalism and to present other modes of conducting historical archaeology.

\section{TRAPPED IN THE NATIONAL CONTAINER}

Social and human sciences have since the Igth century been formed by methodological nationalism (Wimmer \& Glick Schiller 2002; Chernilo 
2008). In studying an aspect of society through archaeology, art history or ethnology, it has been taken for granted that the borders of the nation and its limitations are appropriate as definitions of the field of study. This notion has led to the recurrent confirmation of the relevance of the nation and thus to a repetition of nationalist framework (cf. Aronsson 20II).

Methodological nationalism was first identified by Hermionio Martins in the I970s (Martins 1974), but it became more widespread in the 2 Ist century in the critical discussions on globalization (Chernilo 2008). Methodological nationalism has been defined by Daniel Chernilo as the equation between society and nation-state, as a conceptual reference that is taken for granted (Chernilo 2008:2). Methodological nationalism and the nation-state have been regarded as a power container in the words of Anthony Giddens (Giddens 1987:I3) - a national container restraining understanding of past and present societies other than through the form of the nation.

Through the scope of methodological nationalism, scientific observations of the early modern and modern periods that were made in the peripheries became relevant only by being brought to the centre and thus by underlining the supremacy of Western culture. At the same time as the "discoveries", a new notion of history was born. The idea of Roman legacy became the paramount hegemonic cement together with Christianity in founding the idea of scientific knowledge and the 'Other' (Mignolo I995; Jonsson 200I:2 I-42; Gosden 2004:25ff, I5 If). In this perspective there is a clear connection between early modern Eurocentrism and methodological nationalism of modernity.

The frames of methodological nationalism have been even stronger in cultural history than in the social sciences. Archaeology of the 19th and 2oth centuries became a willing servant in the construction of a suitable and usable past in the birth of a modern nation and the transition of power from the aristocracy to the bourgeoisie (Hobsbawm \& Ranger 1987; Anderson I991; Thomas 2004). Archaeological methods and material culture played an important role in classifications of people and constructions of cultures and thus in serving the ideas of the Western project and nationalism (Thomas 2004:46-52). But the late 2oth and early 2 Ist centuries involved a shift in scientific focus through the escalating globalization and proclamation of the end of grand narratives. This was a welcome development implying a sound criticism of the modern project and its offspring: the Holocaust, sterilization, and the idea of racial hygiene (Bauman I99I). However, archaeological answers to this challenging turn have until recently meant that the discipline had to make do with small-scale case studies, which led to a nec- 
essary critique of previous studies and biases of archaeology but not to a widening of the field of study (cf. Andrén 2009).

What kind of narrative is archaeology providing if it is only to be based on small-scale studies or regional surveys? Has the reluctance to use grand storytelling led to an empiricism which does not dare to challenge society with a relevant discussion about the past? We believe that too many small-scale studies in historical archaeology will confirm the view of the past as small pieces within the grand Western narrative that of the Nation and of Western civilization - which lack ties to the world beyond. Our worry is that archaeology is turning into the study of fictional children's book worlds in a Beatrix Potter format where social equilibrium, stability and homogeneity are both the preconceptions and the results.

By presenting two examples which can be further described as the stress on internal development and the still existing Eurocentric exoticism, our intention is to give an idea of some of the limitations of an archaeology restricted to methodological nationalism, and to show how a too narrow-minded Eurocentric perspective hinders the historical archaeology in the Nordic countries from developing into a modern, reflecting and theory-conscious discipline.

\section{THE IDEA OF THE INTERNAL DEVELOPMENT}

National pride, ignorance and difficulties in dealing with infected issues of the past like slavery and genocide - these are just some of the reasons why worldwide phenomena such as colonialism, capitalism and modernity are often seen as internal histories (e.g. Trouillot I995; Johnson 2006; Leone 2009). Another contributing factor is a prevailing Eurocentrism which implies that historical archaeology by tradition is associated with people of European origin (e.g. Funari I999; Johnson 2006; Gaimster \& Majewski 2009; Leone 2009). With such an approach, any intercultural relation and the participation of non-European peoples and societies are easily overlooked.

A case in point is Matthew Johnson's pivotal study of nascent capitalism, An Archaeology of Capitalism (1996), where he largely avoids the world outside Great Britain (i.e. England). This narrative - capitalism as an interior English process - is not just a simplification; it also strengthens the idea of Western colonialism as a peripheral factor in the advent of capitalism (Johnson I996:272). In its extension it proclaims one of the most important historical processes of global history of the last 500 years as an internal factor. Without doubt Johnson's work has 
challenged our ideas of the potential of historical archaeology, but in his taken-for-granted Anglocentrism there is still considerable work to be done to confront the main haunts of historical archaeology.

However, we need not go to British archaeology to find examples of surviving methodological nationalism. Scandinavian archaeologies of the early modern and modern periods most often take for granted the boundaries of nation-states as relevant scientific frameworks. For example, studies of Swedish early modern society in the I7th and I8th centuries show an academic interest which halts at the borders of the nation-state or at most at the European royal courts. This is certainly true regarding history but also archaeology (Englund 2000, 2006; Wetterberg 2002; Ersgård et al. 2007; cf. also Müller et al. 20I0; Nordin 2010 , in press). The unwillingness to see beyond the national frontiers means that global perspectives of the early modern imperialistic states, the foundation of the Enlightenment as well as the industrial revolution are often ignored. Moreover, to overlook the global impact on courses of action that are explicitly connected to material culture, such as the colonial commodification process, disconnects the tacit links between the Nordic countries and the rest of the world.

Working on early modern sites automatically implies analyses of artefacts and remains with global histories. Particularly in Sweden, historical archaeology often unearths early modern industrial remains or crofters' dwellings, two kinds of sites emblematic in a discussion of the rise of the industrial and agricultural revolutions, which, even though not identical, took place all over the world at more or less the same time (cf. Welinder 2007). Swedish iron production underwent its heyday exporting iron to Western Europe as well as to the Atlantic world, that is, West Africa and the colonial plantations of North America (Evans \& Rydén 2007). As we will see further ahead, a blast furnace in I 7 thcentury Sweden is thus not just a dot on the map or an industrial site which meant work for a number of people; it is also a key site in understanding the global web of colonialism and capitalism.

Still, the global commodification process consisted of many more practices than just production and trade. Transports, uses, re-uses, destructions and depositions, as well as various forms of valuations from objects to commodities and into fetishes, are equally important parts in the process of understanding the lives of early modern artefacts, no matter if they are Dutch clay pipes, Bellarmine jars of the Rhineland, Chinese teacups or South American gemstones and pearls (Orser 1996; cf. also Marx 1976). The biographical perspective on material culture is a fruitful approach which provides archaeologists with tools for dis- 
cussing the seemingly solitary objects from a contextual point of view (Saunders I999:244; Herva \& Nurmi 2009; Nurmi 20II).

Although it is seldom acknowledged, the commodification process and the biographical chain evidently also worked the other way around, that is, with the spread of Nordic products throughout the world. The Swedish-Indian copper trade in New Sweden (I638-I655) is an example of this. The Lenape and Susquehannock Indians used copper from Sweden, and the Swedes obtained not only livelihood but 'exotic' objects for use both in Sweden and in New Sweden. Swedes brought amongst other things calumet pipes, clubs, axes, wampum beads and pouches which were put into the context of early modern European collections for display. As a consequence, copper inlays of Lenape objects that ended up in Sweden might be of Swedish origin (cf. Becker I990:23; Little 2007:82).

\section{EUROCENTRIC EXOTICISM}

Whereas the traditions of internal developments and small-scale narratives try to avoid the paramount questions of the rise of modern society, our second example, Eurocentric exoticism, is to be seen as a continuous tradition from the heyday of Western colonialism. Colonial artefacts from any context outside Europe were often regarded as neutral "works of art" which could be catalogued and put into the museum collections of the Western world in order to emphasize the European supremacy (cf. Torgovnick I990).

A visit to the famous Skokloster Castle in central Sweden might exemplify this. The castle, one of the best preserved Baroque palaces of Northern Europe, obtained already in the late 17 th century the status of a museum, wunderkammer and monument. The collection of the former owner, Count Carl Gustaf Wrangel, is kept together in situ along with contemporaneous furniture and fine arts. Wrangel filled the castle with symbols of Eurocentrism - most obvious in the great dining hall where the stucco ceiling has depictions of the four, at that time known, continents, corresponding to the four towers of the castle. America and the symbols of the New World have a pivotal position and are depicted as wild, abundant and without history, in contrast to the image of Europe where the Renaissance aesthetics focus on the Roman legacy, symbolized by history, artfulness and modesty (Losman I988; Nordin forthcoming).

In Wrangel's substantial armoury there are objects from the New World. Here anthropomorphic clubs and an axe from the New Sweden area are confronted with modern martial techniques of the mid-I $7^{\text {th- }}$ century Westphalian world. The Lenape Indian objects as well as the 


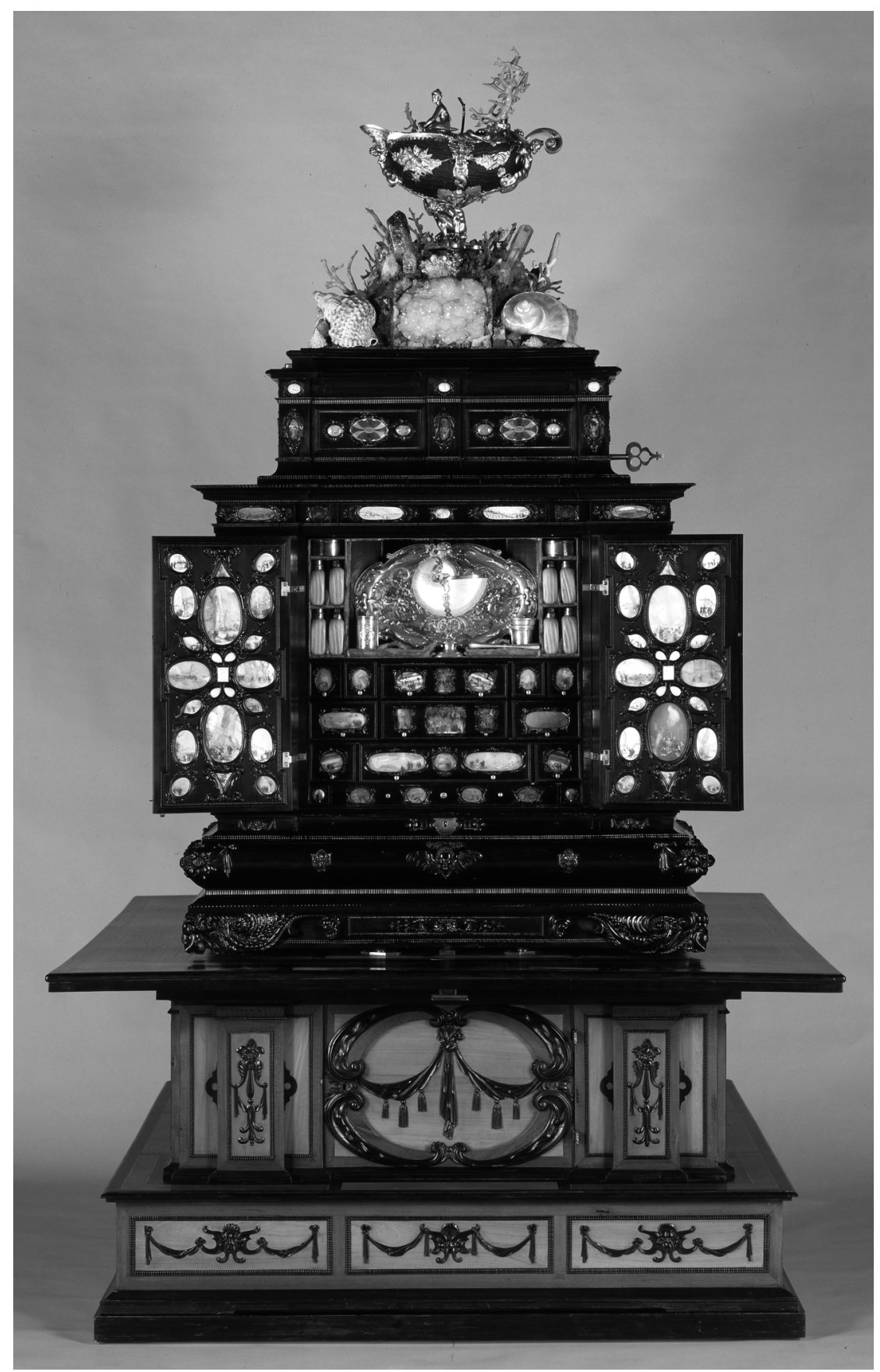

Figure 2. This is not a curiosity cabinet but a physical staging of Eurocentrism. Early I 7 th-century cabinet in Uppsala University, Uppsala. Courtesy of Uppsala Universitets konstsamlingar. 
stucco depictions, although well studied, have been looked upon as solitary exotic objects or representations of exoticism instead of as important statements of the rise of a colonial world (e.g. Losman I988; Becker 1990). The castle, its interior and collections make up a totality representing the colonial ideology of early modern Europe (Nordin forthcoming).

Founders of the Enlightenment in the Nordic countries, such as Linné, Kalm, Sparrman, Niebuhr and Grundtvig, have played important roles in constructing on the one hand a European concept of knowledge about the world, and on the other hand the notion of the 'Other' as an object of study, description, categorization, and finally something to be put into its correct place in the hierarchy of creation (cf. Broberg 1975; Hall 2000:I2If; Hollsten 20I0; cf. Haraway I989:26-58). These travellers in the service of the colonial ideology have also meant a lot to archaeology by providing first-hand descriptions of past societies and by attempting to categorize different species and artefacts.

A somewhat Eurocentric approach towards non-European objects from the colonial period, one that is based on colonial epistemology, still prevails among Nordic scholars. While art historians have long embraced exotic objects from the New World and seen them as reflecting the refined and cosmopolitan taste of the early modern elite in Europe, the same artefacts are generally ignored by archaeologists (cf. Snickare 2OII). One reason is of course that these kinds of things are rarely found at archaeological sites; their enigmatic materiality also makes them a hidden category of objects that is often relegated to the museum's curiosity departments without any further analysis. But most of all, nonEuropean artefacts does not fit into the stories produced in small-scale narratives since a substantial part of their biographies must be sought outside the national borders.

Still, it is a fact that rare foreign objects did exist and were widely used and displayed all over Europe - including the Nordic countries throughout the colonial era, alongside with more mundane things we generally find on archaeological sites. We must also remember the global scale of the mass material of early modern society - the clay pipes, glass, and ceramics - and acknowledge its tacit relation to the plantations, industries and modes of transportation as an ongoing narrative related to the actual use in the past. Edward Said's study on Jane Austen's Mansfield Park might serve as an inspiration (I993:95-II6). The social relations in the centre, at the late I8th-century estate of Mansfield Park in England, are directly related to the economic base in the periphery: the slave plantations on Antigua. The one cannot be understood without the other. 


\section{TOWARDS AN ARCHAEOLOGY OF GLOBAL RELEVANCE}

In previous sections, we have tried to illustrate the main limitations with a historical archaeology that ignores global synthesis and perspectives. We have seen how archaeologies restricted to a storytelling that emanates from local or national frameworks serve only to conserve the prevailing order of things according to the idea of Western supremacy. However, our stance is not new. Similar criticisms have been put forward by several archaeological scholars before, especially in terms of postcolonial arguments against essentialist and Eurocentric viewpoints (e.g. Funari 1999; Johnson 2006; Gaimster \& Majewski 2009; Leone 2009). In this context, the term 'postcolonial' should be interpreted as Stuart Hall puts it: a decentred, diasporic or global reviewing of earlier, nation-centred, imperial grand narratives (Hall I996a:247). As a consequence of breaking the European hegemony and putting attention on societies outside Europe, many postcolonial theorists have developed topics where non-Europeans or subaltern peoples (marginalized groups) are considered as agents of political and social change (e.g. Spivak I988; Bhabha 1994; Hall 1996b, 1997; Chakrabarty 2000). At the moment, this approach is receiving considerable resonance in the archaeologies of former colonies like the United States and South Africa (cf. Hall 2000; Leone 2009), in which these peoples have usually been omitted.

We believe in an archaeology that confronts the modern grand narrative, not through capitulation into small harmless site studies but by facing the foundations of Western society. An archaeology that solely emanates from national borders maintains a persistency in stereotyped power relations and belittling representations of peoples from the outside, which only reduce our understanding of heterogeneous structures and relations of the past (cf. Liebmann 2008; Jordan 2009; Lihammer 20II). This is especially relevant when dealing with issues such as early modern colonialism, capitalism or modernity, where neglecting nonEuropean agency entails silencing peoples and artefacts as well as activities and interrelations between different peoples (cf. Trouillot 1995, 2002; Hall \& Silliman 2006). The consequences are quite serious since it actually means ignoring a significant part of the material culture, social practices and consumption patterns that were adopted from the New World and its inhabitants and that had major significance for early modern Europeans and their construction of identity. Our firm position is that European wealth, culture and Enlightenment would never have made such rapid progress without the significant contribution of Afri- 
can, American and Asian culture, capital and human lives (Williams I994; Gilroy 1993; Blackburn 2010).

This contribution led to hybridization, where African, American, Asian and European material culture and identity mingled and laid the foundation of modern society. Thus West African and North American societies as well as the Nordic are results of ongoing enunciations of identity and power through the whole history of modernity (cf. Bhabha 1994).

In the subsequent sections we present a re-reading of colonial experiences during the early modern period by looking at aspects of material culture and worldwide connections that have long been excluded from the archaeological discourse in the Nordic countries. Once again, we would like to reiterate that our intention is not to create an archaeological agenda of the 'outside' but rather to demonstrate how the 'outside' influenced and was used to reproduce new social practices, identities and power relations on the 'inside'. The following themes mainly concern aspects of consumerism, collecting and production since they intimately link to the material culture we often face at early modern sites.

\section{CONSUMING THE NEW WORLD}

The colonial encounter with the world outside Europe and its inhabitants forever changed the lives of the Europeans. If you were not a sailor, merchant, planter or belonged to the contemporary upper class in early modern Europe that could afford black servants or entertainers, you would probably never directly encounter a non-European person from the colonies, even if it is proven that they existed in surprisingly large numbers in some colonial mother countries (cf. Amussen 2007:I77226). However, through material culture the great majority of Europeans came in contact with the New World. The distribution, commerce and availability of all sorts of foreign commodities were a concern for the whole of Europe, including the Nordic countries. Initially, colonial objects were seen as luxurious and exotic items only obtainable for the aristocracy. But when mass importation and consumption seriously began to spread in the I8th century, the majority of consumer goods like coffee, tobacco and sugar as well as medicinal plants and other botanical specimens were available to a growing proportion of the population (e.g. Mintz 1985; Schiebinger \& Swan et al. 2007; Norton 2008; Rönnbäck 2009).

In this context it is relevant to mention new finds in contract archaeology and the emphasis on method development that has prevailed in 
Sweden this last decade. For example, the discovery of macrofossils related to tobacco cropping and clay pipes already in the late I6th century in Sweden speaks for an influx of luxury commodities in a much earlier period than previously thought (Heimdahl 2005:37f). These results also point to a much more socially widespread use of tobacco which is not traceable through written records. Early modern globalization has a potential to come to life through the material culture if archaeologists only start to look.

Foreign commodities promptly became an essential part of everyday life, and this pattern of consumption is rooted so deeply in the Nordic fabric today that we seldom reflect on its origin. Maybe this somewhat Eurocentric stance is one reason why non-European agency in colonial contexts has long been a neglected field of research in Nordic historical archaeology. In the following section, we make a swift leap that touches upon how non-European meanings, knowledge and practices were attached to many colonial objects and commodities when possessed, as well as what these artefacts emotionally evoked in the Europeans who re-used or viewed them (e.g. Saunders I999; Loren 20I0). We are aware that this approach does not automatically mean visualizing non-European peoples, but it might open up for a new, more versatile way to recognize the global impact of the material culture in Europe, which all too often we take for granted as typically domestic.

We have chosen to approach the problem by starting with a broader definition of early modern consumption that goes beyond the traditional, and somewhat simplified, perception which claims that colonial consumption is more or less synonymous to consumer goods such as sugar, tobacco, coffee and cotton. Our view is that consumption did not solely consist of mass-produced commodities that were depleted; it also consisted of contemporaneous acquisition of non-European knowledge and social practices, and even collecting and displaying objects can be considered as different expressions of consuming the New World (cf. Sheller 2003). It is important to bear in mind that the material culture from the New World did not arrive in Europe as isolated enclaves; most objects were imported as parts of larger contextual settings. That is why we have to be open to parallel and reversed biographies and a widely defined concept of consumption that puts attention on the various scenarios in which the foreign objects appear.

This view might be illustrated by the implications of the extensive importations of tobacco and cocoa, which reveal that pre-Columbian usage and social practices were deeply embedded in these products when they first arrived in Europe. Tobacco and cocoa are - contrary to many preconceptions - examples of commodities that the Europeans first took an 
interest in when they realized that the consumption was associated with upper-class practices among the indigenous people of the New World (Norton 2008:50). Initially Europeans seized the spiritual and medicinal values that the indigenous people connected with the use of the products. Magical and mystical beliefs surrounding the products certainly increased the aura of exoticism and thus the economic value on the European market. But when tobacco and cocoa became widespread consumer goods in Europe during the I8th century, the use was secularized - or to use Saunders' word recontextualized - as part of the demystification process (i.e. Saunders 1999:246). When tobacco and cocoa were given new cultural identities, they fitted better into the European consumer culture that was based on social gatherings and public display.

Although the indigenous significations of cocoa were recontextualized over time, the European import of Mexican vessels like tecomate and xicaras, which the local people used for sipping chocolate, and other associated items such as the molinillo, the obligatory chocolate beater, continued (Norton 2008:I69f). It is likely that the utensils' immediate connection to chocolate gradually faded away, but their existence endured in new scenarios as exclusive and rare objects to collect and display. This is especially notable in contemporaneous still-life paintings where they are frequently depicted together with other overseas objects. Another example of a material culture that travelled from Western Europe to the Americas is the stoneware chamber pots transformed into Colono ware in the Chesapeake and with the shape of a vessel bringing a specific relation to excrement to new users among Afro-Americans and Native Americans (Ferguson 1992:52-53).

It is well known that the ceaseless quest for new sources of economic income enticed the Europeans to exoticism and otherness, which they believed that the non-European material culture represented - a view that also sustained colonialism as a Eurocentric project. The growing urge to possess artefacts from other cultures during the early modern period can be interpreted as an expression of contemporaneous luxury consumption and consequently a new aspect of aristocratic identity (e.g. Peck 2005; Eriksdotter 2010). Our experience of the exoticism of the indigenous peoples' utensils for chocolate should definitely be seen in this context. The obsession for luxuries also opened the door for trade scenarios with other foreign objects which were believed to have supernatural properties. Items like bezoars, narwhal tusks, ivory, ostrich eggs, peculiar bone fragments, shells, feather works and gemstones - to name a few - were used both for their desirable magical effects and as exclusive objects to collect and display in curiosity cabinets. 
Thousands of these artefacts are still preserved today, visible in showcases and in secret drawers of curiosity cabinets throughout Europe. The tradition came to the Nordic countries in the mid I60os, and since Sweden was one of Europe's biggest promoters of luxury consumption during the so-called Era of Greatness, royalties as well as many aristocratic families throughout the country were all in possession of several cabinets whose foreign contents were studied and admired by amazed visitors (e.g. Losman I988; Boström 200I; Beijer 20I0).

A curiosity cabinet's artefacts constitute a unique - and too often archaeologically neglected - source of information on how indigenous magical and spiritual functions were left untouched, at the same time as they were given new significance in European settings. The floating meanings resulted in that objects such as bezoar stones were believed to be an elixir of life according to indigenous cosmovisions, as well as being the invincible cure for the plague that harassed Europe during the I 7 th century (Eriksdotter 20IO:43). With parallel biographies or hybrid meanings taken from both the Old and the New World (i.e. Liebmann 2008:2), the objects attracted a larger audience, which increased the demand and their values.

The cabinets were not only, as many scholars maintain, multifunctional instruments with which to share knowledge, conduct diplomacy, and, if needed, to use as pragmatic tools for economic statecraft (Meadow 2002:I82). Thomas Kaufmann's alternative view uncovers a much closer relationship to non-European peoples by interpreting the cabinets as a microcosm with the intention of reflecting a macrocosm, like a theatrum mundi (Kaufmann I994:I 45ff). By owning a microcosm which physically meant items from all around the world, the possessor believed that he or she had control of the geographical places they came from (cf. Herva 20Io).

Far away from the New World and its inhabitants, early modern Europeans used the foreign and exotic objects, the colonial consumer goods, and the indigenous social practices as extensions of absent nonEuropeans in order to sustain European identity and consequently their perceived hierarchy and status. Hence, the people from the 'outside' were constantly present.

\section{PRODUCTION AND THE BIRTH OF CAPITALISM}

The emergence of the consumer revolution in I7th-century Europe is closely linked to the colonial expansion of the New World (Hall \& Silliman 2006). Worldwide mobilization of financial resources, large-scale 
plantations and a modern bureaucracy permitted the colonies to produce desirable commodities for a growing market in Europe. A global economy was created which tied together commodities, people and cultures, voluntarily or with coercion, through relations of production and consumption (Sheller 2003:7).

With regard to production and consumption, the one cannot be understood without the other, and without consumption there would be no production. However, epistemological tradition in Western social science has emphasized the conditions of modes of production (Marx I976) and the role of religion in stimulating a higher level of production (Weber 200I). Although it was pivotal, neither Marx nor Weber fully examined the role of consumption for the conditions of production and the rise of early capitalism. The production quotas of Northern and Western Europe increased throughout the early modern period, not only because of the concentration of production at the plantations in the New World, but also because of the mining districts and industrial production throughout Western Europe (Belford 2008).

Recent studies in the history of economics have acknowledged this fact and discussed it in terms of the rise of a new culture of diligence, which coloured the early modern period (de Vries 2008; Rönnbäck 2009). Without a doubt, Werner Sombart's notion of the role of luxury consumption for nascent capitalism has been revitalized (Sombart I922). As a result of the luxury consumption Jan de Vries has noted a widespread staggered production (de Vries 2008:89ff). People of early modern Europe produced more in order to consume more. The global migrations of slaves, indentured workers and contract workers which escalated in the 17 th century can be related to a need to increase production to enable the growing consumption. Hence, Weber's idea of the Protestant's hardy work and limited consumption must be adjusted.

The strenuous Protestants can still be looked upon as important motors of capitalism, but their spin of the wheel of commerce was not so much about production as consumption, a fact obvious when looking at contemporaneous centres of consumption such as Amsterdam and London. The Protestant ethic is thus founded on both production and the Protestant's eagerness to consume products such as beaver pelt hats from North America, tobacco from Virginia, as well as silver from South America and spices from the Far East.

For archaeologists - used to discussing both consumption and production - this points towards promising possibilities for future studies. The small-scale industrial sites often found in archaeological surveys and investigations in the Nordic countryside are thus not only key sites 


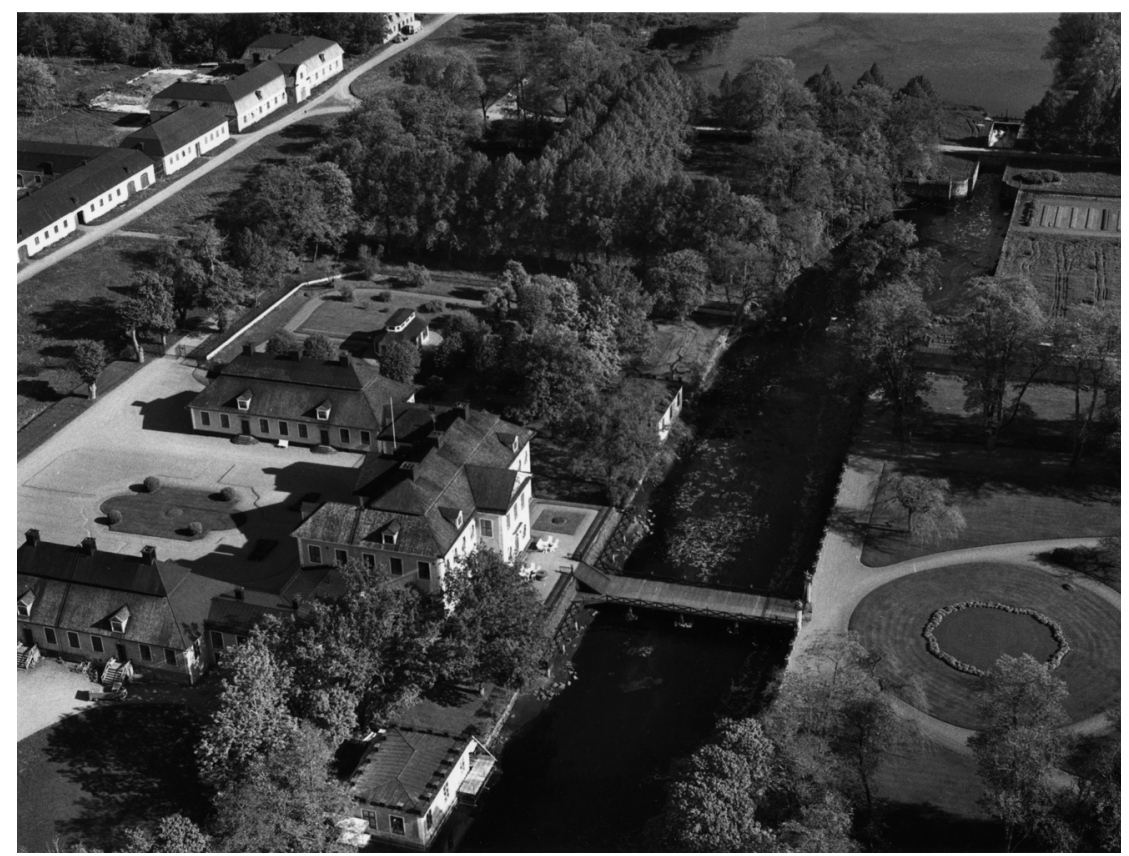

Figure 3. This is not an eighteenth century iron works but a local production of the global plantation. Lövstabruk manor early i8th century. Photo ATA 1966.

to understanding modes of production, but also a reflection of the new consumer behaviour of the early modern and modern periods.

A major industry such as Lövstabruk in northern Uppland, Sweden, underwent a significant change in the I 7 th century which can be connected to contemporaneous economic and social changes in the Atlantic world. The industry was founded in Lövstabruk in the I6th century as a peasant-run furnace and a royal iron works. Initially it was small scaled with buildings scattered around the natural falls of the river (Nordström I987:II3; Hildebrand 1992). The changes commenced in the I620:s when the Dutch industrialist Louis De Geer took over the production and started to development a society founded on modern production methods. At the end of the I7th century, the industrial setting was totally transformed into a geometrically strict panopticon. The ideally planned town with a church, manor, gazebos, renaissance garden, canals and workers' houses is a mirror of the contemporary Atlantic ideal landscape and town planning identified by Henry M. Miller (1988) and Mark Leone \& Paul Shackel (I990). The majority of the early modern iron works of Sweden were in fact local versions of global plantations (Evans \& Rydén 2007:2II). 
It is through studies of smithies and workshops that we find the keys to understanding the everyday consumption in the semi-periphery of the early modern global world. Technical changes in the industrial landscape and changes in the mode of production in the early modern society can be linked to changes in consumption patterns and are thus important to study in order to understand consumption as such.

The consumer behaviour of the early modern period laid the foundation of our own society's obsession with economic growth - a consumption culture linked to a production that is devastating for the planet because it ends in global warming and decreased natural resources.

\section{CONCLUSION}

Historical archaeology in the Nordic countries as in the rest of the world is in a vital and expanding state. Few subjects seem too remote for archaeologists to study. However, the borders of nations and their scientific offspring the methodological nationalism are obstacles in this development. Archaeologists still tend to look at the past through the divisions of nation-states. Consequently, historical archaeologists study a period of globalization with global source materials but their interpretations are often framed by national contexts.

Influenced by the critique of the grand narratives of modern society and the modern project, the development in these last decades has turned the practice of archaeology into detailed case studies on local and regional levels. This was a natural development in the light of postmodern critique of the grand narrative, but as we argue in this article, it is time for archaeology of the modern periods to deal with the consequences of historical and contemporary globalizations. Our conviction is that historical archaeology should not focus on imagined national pasts, but rather study the preconditions of modernity, colonialism, globalization, and the rise of capitalism.

In this brief account we have tried to suggest possible paths towards a historical archaeology of global relevance. The article is a reaction against the failure to account for the material aspects of globalization which in the end subsidize a single and non-problematic archaeology. We argue that past societies ought to be seen as pluralized and decentred in order to uncover the multifaceted and ambiguous meanings of early modern material culture.

We have shown through various examples that the global perspective can only be understood if we acknowledge the limitations of methodological nationalism and start to investigate the tacit links that existed 
between the Nordic countries and the rest of the world. Our discussion has mainly dealt with the global relations of the early modern period, traceable through material culture in Scandinavia. Emphasis has been put on three important pillars of past societies: consumption, production and collection. Acknowledging these factors, we suggest a bright future for historical archaeology that is more relevant to contemporary society. The archaeologists and their surrounding societies would no longer be living globally and thinking nationally, but rather living global lives through both theory and practice.

Gunhild Eriksdotter Gotland University, Institutionen för kultur, energi och miljö 62I 67 Visby

Jonas M. Nordin The National Historical Museum Box 5428, II 484 Stockholm

\section{REFERENCES}

Amussen, S. D. 2007. Caribbean Exchanges. Slavery and the Transformation of English Society I640-I700. Chapel Hill: The University of North Carolina Press.

Anderson, B. I99I. Imagined Communities. Reflections on the Origin and Spread of Nationalism. London: Verso.

Andrén, A. 2009. Den stora berättelsens återkomst. In: Artelius, T. \& Källström A. (Eds). Arkeologisk framtid: rapport från Svenskt arkeologmöte 2008: Pp. 69-77. Lund: Svenska Arkeologiska Samfundet.

Aronsson, P. 20I r. Explaining National Museums: Exploring Comparative Approaches to the Study of National Museums. In: Knell, S. J. Aronsson, P. \& Amundsen, A. B. (Eds). National Museums. New Studies from around the World. Pp. 29-54. London: Routledge.

Bauman, Z. I991. Modernity and the Holocaust. Cambridge: Polity Press.

Becker, M. J. I990. 'Two I7th Century Clubs in the Collections of the Skokloster Museum, Sweden. Native American Studies. 4:I. Pp. I9-28.

Belford, P. 2008. Steel at the Dawn of Capitalism: Reformation, Technology and Enlightenment. Historical Metallurgy. 42:2. Pp. 89-99.

Beijer, G. (Ed.). 20Iо. Kunglig glans: måleri, konsthantverk och möbler. Stockholm: Arena.

Bhabha, H. 1994. The Location of Culture. New York: Routledge.

Blackburn, R. 20Io. The Making of New World Slavery. From the Baroque to the Modern I492-I800. London: Verso.

Boström, H. 200I. Det underbara skäpet: Philipp Hainhofer och Gustav II Adolfs konstskåp. Uppsala: Acta Universitatis Upsaliensis. 
Broberg, G. I975. Homo Sapiens L. Studier i Carl von Linnés naturuppfattning och människolära. Stockholm: Almqvist \& Wiksell.

Chakrabarty, D. 2000. Provincializing Europe. Postcolonial Thought and Historical Difference. Princeton: Princeton University Press.

Chernilo, D. 2008. Methodological Nationalism: Theory and History. Annual Conference of the International Association of Critical Realism King's College, London July 2008. http://www.kcl.ac.uk/depsta/law/events/o708/iacr/papers/Chernilo_ Methodological_Nationalism.pdf. Accessed on 7th October 20 I I.

Englund, P. 2000. Den oövervinnerlige: om den svenska stormaktstiden och en man $i$ dess mitt. Stockholm: Atlantis.

Englund, P. 2006. Silvermasken: en kort biografi över drottning Kristina. Stockholm: Bonnier.

Eriksdotter, G. 20I0. Dolda laster? Magi och modernitet speglat genom colonial handel i den Nya världen under I600-talet. In: Lihammer, A. \& Nordin, J. M. (Eds). Modernitetens materialitet. Arkeologiska perspektiv på det moderna sambällets framväxt. The Museum of National Antiquities, Studies I7. Pp. 27-45. Stockholm: The Museum of National Antiquities.

Ersgård, L. (Ed.). 2007. Modernitet och arkeologi. Artiklar från VIII Nordic TAG $i$ Lund 2005. Stockholm: Riksantikvarieämbetet.

Evans, C. \& Rydén, G. 2007. Baltic Iron in the Atlantic World in the Eighteenth Century. The Atlantic World XIII. Leiden: Brill.

Ferguson, L. 1992. Uncommon Ground. Archaeology and Early African America, I650-I800. Washington: Smithonian Institution Press.

Foster, J. B. 1999. Marx's Theory of Metabolic Rift: Classical Foundations for Environmental Sociology. American Journal of Sociology. 105:2. Pp. 366-405.

Funari, P. I999. Historical Archaeology from a World Perspective. In: Funari, P., Hall, M. \& Jones, S. (Eds). Historical Archaeology: Back from the Edge. Pp. 37-66. London: Rouledge.

Gaimster, D. \& Majewski, T. (Eds). 2009. International Handbook of Historical Archaeology. New York: Springer.

Giddens, A. 1987. The Nation state and Violence. Volume two of a Contemporary Critique of Historical Materialism. Berkeley: University of California Press.

Gilroy, P. 1993. The Black Atlantic. Modernity and Double Consciousness. Cambridge Mass: Harvard University Press.

Gosden, C. 2004. Archaeology and Colonialism. Cultural Contact from 5000 BC to the Present. Cambridge: Cambridge University Press.

Hall, M. 2000. Archaeology and the Modern World. Colonial Transcripts in South Africa and the Chesapeake. London: Routledge.

Hall, M. \& Silliman, S. W. 2006. Introduction: Archaeology of the Modern World. In: Hall, M. \& Silliman, S. W. (Eds). Historical Archaeology. Pp. I-22. Victoria: Blackwell Publishing.

Hall, S. I996a. When was 'the Post-Colonial'? Thinking at the Limit. In: Chambers, I. \& Curti, L. The Post-Colonial Question: Common skies, divided horizons. Pp. 242-260. London: Routledge.

Hall, S. I996b. The West and the Rest. Discourse and Power. In: Hall, S., Held, D., Hubert, D. \& Thompson, K. (Eds). Modernity. An Introduction to Modern Societies. Pp. I84-228. Malden: Blackwell. 
Hall, S. 1997. The spectacle of the 'Other'. In: Hall, S. (Ed.). Representation. Cultural Representations and Signifying Practices. Pp. 223-279. London: Sage.

Haraway, D. 1989. Primate Visions. Gender, Race, and Nature in the World of Modern Science. London: Routledge

Heimdahl, J. 2005. Archaeobotanical Evidence of Early Tobacco Cultivation in Norrköping, Sweden (Manuscript).

Herva, V.-P. 20Io. Maps and Magic in Renaissance Europe. Journal of Material Culture. Vol. I5. Pp. 323-343.

Herva, V.-P. \& Nurmi, R. 2009. Beyond Consumption: Functionality, Artefact Biography and Early Modernity in a European Periphery. International Journal of Historical Archaeology. I3:2. Pp. I58-I82.

Hildebrand, K.-G. 1992. Swedish Iron in the Seventeenth and Eighteenth Centuries. Export Industry before Industrialization. Stockholm: Jernkontorets Bergshistoriska Skriftserie 29.

Hobsbawm, E. \& Ranger, T. (Eds). 1987. The Invention of Tradition. Cambridge: University Press.

Hollsten, L. 20IO. Pehr Kalms skildring av resan till England och Amerika I747-I75 I som global miljöhistoria. In: Müller, L. Rydén, G. \& Weiss, H. Global historia från periferin. Norden I600-I850. Pp. 23 I-253. Lund: Studentlitteratur.

Johnson, M. 1996. An Archaeology of Capitalism. Oxford: Blackwell.

Johnson, M. 2006. The Tide Reversed: Prospects and Potentials for a Postcolonial Archaeology of Europe. In: Hall, M. \& Silliman, S. W. (Eds). Historical Archaeology. Pp. 3I3-33I. Victoria: Blackwell.

Jonsson, S. 200I. Världens centrum: en essä om globalisering. Stockholm: Norstedt.

Jordan, K. 2009. Colonies, Colonialism and Cultural Entanglement: The Archaeology of Postcolumbian Intercultural Relations. In: Majewski, T. \& Gaimster, D. (Eds). International Handbook of Historical Archaeology. Pp. 3 I-50. New York: Springer.

Kaufmann, T. I994. From Treasury to Museum: The Collections of the Austrian Haubsburgs. In: Elsner, R. \& Cardinal, R. (Eds). The Cultures of Collecting. Pp. I37-I54. London: Reaktion Books.

Leone, M. 2009. Making Historical Archaeology Postcolonial. In: Majewski, T. \& Gaimster, D. (Eds). International Handbook of Historical Archaeology. Pp. 159I68. New York: Springer.

Leone, M. \& Shackel P. I990. Plane and Solid Geometry in Colonial Gardens in Annapolis, Maryland. In: Kelso, W. M. \& Most, R. (Eds). Earth Patterns. Esssays in Landscape Archaeology. Pp. I53-167. Charlottesville: University Press of Virginia.

Liebmann, M. 2008. Introduction: The Intersections of Archaeology and Postcolonial Studies. In: Liebmann, M. \& Rizvi, U. (Eds). Archaeology and Postcolonial Critique. Pp. I-20. Lanham: Altamira Press.

Lihammer, A. 20I . The Forgotten Ones. Small Narratives and Modern Landscapes. The Museum of National Antiquities, Stockholm. Studies I8. Stockholm: The Museum of National Antiquities.

Little, B. J. 2007. Historical Archaeology: Why the Past Matters. Walnut Creek: Left Coast Press.

Little, B.J. \& Shackel, P.A. 2007. (Eds). Archaeology as a Tool of Civic Engagement. Lanham: Altamira Press. 
Loren, D. D. 20I0. The Exotic of Daily Life: Trade and Exchange in Historical Archaeology. In: Dillian, C. D. \& White, C. L. (Eds). Trade and Exchange: Archaeological Studies from History and Prehistory. Pp. 195-204. New York: Springer.

Losman, A. I988. Skokloster - Europe and the World in a Swedish Castle. In: Losman, A. (Ed.). The Age of New Sweden. Pp. 85-гог. Stockholm: Livrustkammaren.

Martins, H. 1974. Time and Theory in Sociology. In: Rex, J. (Ed.) Approaches to Sociology. Pp. 249-254. London: Routledge.

Marx, K. 1976 [1867]. Capital. A Critique of Political Economy. Vol. I. Harmondsworth: Penguin in association with New Left Review.

Meadow, M. 2002. Merchants and Marvels: Hans Jacob Fugger and the Origins of the Wunder Kammer. In: Smith, P. \& Findlen, P. (Eds). Merchants and marvels: commerce, science and art in early modern Europe. Pp. 182-200. New York, Routledge.

Mignolo, W. 1995. The Darker Side of the Renaissance. Literacy, Territoriality and Colonization. Ann Arbor: The University of Michigan Press.

Miller, H. 1988. Baroque Cities in the Wilderness: Archaeology and Urban Development in Colonial Chesapeake. Historical Archaeology. 22:1. Pp. 57-73.

Mintz, S. W. 1985. Sweetness and Power: The Place of Sugar in Modern History. New York: Viking.

Müller, L., Rydén, G. \& Weiss, H. 20I0. Global historia från periferin. Norden I600I 850 . Lund: Studentlitteratur.

Nordin, J. M. 2009. Den iscensatta medeltiden och drömmarna om moderniteten: historiebruket vid Stockholmsutställningen I897. Med historien i ryggen. Forntiden och medeltiden i nordisk historieanvändning. In: Edquist, S. Hermansson, L. \& Johansson, S. (Eds). The Museum of National Antiquities, Studies I3. Pp. 223-248. Stockholm: The Museum of National Antiquities.

Nordin, J. M. 20I0. Det emblematiska silvret. Sverige i den atlantiska världen vid I600-talets mitt. In: Lihammer, A. \& Nordin, J. M. (Eds). Modernitetens materialitet. Arkeologiska perspektiv på det moderna sambällets framväxt. The $\mathrm{Mu}-$ seum of National Antiquities, Studies I7. Pp. 47-70. Stockholm: The Museum of National Antiquities.

Nordin, J. M. 20I I. Archaeology in the World of Display: A Material Study of the Use of History in the Stockholm Exhibition of I897. International Journal of Historical Archaeology Vol.15. Pp. 358-380.

Nordin, J. M. In press. 'Embodied Colonialism: The Cultural Meaning of Silver in a Swedish Colonial Perspective in the Seventeenth Sentury.' Journal of Post Medieval Archaeology. Under publication $20 \mathrm{II}$.

Nordin, J. M. (Forthcoming). The Centre of the World. The Material Construction of Eurocentric Domination and Hybridity in a Scandinavian Seventeenth Century Context.

Nordström, A. 1987. Bergsmän och brukspatroner. Stockholm: Gidlunds.

Norton, M. 2008. Sacred Gifts, Profane Pleasures. A History of Tobacco and Chocolate in the Atlantic World. London: Cornell University Press.

Nurmi, R. 20I r. Development of the Urban Mind-An Object Biographical Approach. The Case Study of the Town of Tornio, Northern Finland. Oulu: Uniprint.

Orser, C. 1996. A Historical Archaeology of the Modern World. New York: Plenum Press. 
Peck, L.L. 2005. Consuming Splendor: Society and Culture in Seventeenth Century England. Cambridge: Cambridge University Press.

Rönnbäck, K. 2009. Commerce and Colonialism: Studies of early Modern Merchant Capitalism in the Atlantic Economy. Gothenburg Studies in Economic History 3. Göteborg: University of Gothenburg.

Said, E. I993. Culture and Imperialism. London: Chatto \& Windus.

Saunders, N. J. I999. Biographies of Brilliance: Pearls, Transformations of Matter and Being, c. AD I 492. World Archaeology. Vol 31, no 2. Pp. 243-257.

Schiebinger, L. \& Swan, C. (Eds.). 2007. Colonial Botany. Science, Commerce and Politics in the Early Modern World. Philadelphia: University of Pennsylvania Press.

Shackel, P. 2004. Labor's Heritage: Remembering the American Industrial Landscape. Historical Archaeology. Vol. 38. Pp. 44-58.

Shackel, P. \& Chambers, E. J. (Eds). 2004. Places in Mind. Public Archaeology as Applied Anthropology. London: Routledge.

Sheller, M. 2003. Consuming the Caribbean. From Arawaks to Zombies. London: Routledge.

Snickare, M. 20I I. The King's Tomahawk: On the Display of the Other in SeventeenthCentury Sweden, and After. Konsthistorisk tidskrift. Vol. 80. Pp. I24-I35.

Sombart, W. 1967 [1922]. Luxary and Capitalism. Ann Arbor: University of Michigan Press.

Spivak, G. C. 1988. Can the Subaltern Speak?. In: Nelson, C. \& Grossberg, L. (Eds). Marxism and the Interpretation of Culture. Pp. 27 I-3I4. Urbana: University of Illinois Press.

Thomas, J. 2004. Archaeology and Modernity. London: Routledge.

Torgovnick, M. I990. Gone Primitive. Savage Intellect, Modern Lives. Chicago: The University of Chicago Press.

Trouillot, M.-R. I995. Silencing the Past. Power and the Production of History. Boston: Beacon Press.

Trouillot, M.-R. 2002. The Otherwise Modern. Caribbean Lessons from the Savage Slot. In: Knauft, B. M. (Ed.). Critically Modern. Alternatives, Alterities, Anthropologies. Bloomington: Indiana University Press.

de Vries, J. 2008. The Industrious Revolution: Consumer Behavior and the Household Economy, I650 to the Present. Cambridge: Cambridge University Press.

Weber, M. 200I. [1934] Protestant Ethic and the Spirit of Capitalism. London: Routledge.

Welinder, S. (Ed.). 2007 Torpens arkeologi. Stockholm: Riksantikvarieämbetet.

Wetterberg, G. 2002. Kanslern, Axel Oxenstierna i sin tid I-2. Stockholm: Atlantis.

Williams, E. 1994 [1944]. Capitalism and Slavery. Richmond: North Carolina Press.

Wimmer, A. \& Glick Schiller, N. 2002. Methodological Nationalism and Beyond: Nation-State Building, Migration and the Social Sciences. Global Networks 2. Pp. $30 \mathrm{I}-334$. 